\title{
CONFIRMED OCCURRENCE OF MOONTAIL BULLSEYE, PRIACANTHUS HAMRUR (ACTINOPTERYGII: PERCIFORMES: PRIACANTHIDAE), IN THE MEDITERRANEAN SEA WITH FIRST RECORD OFF THE COAST OF TURKEY
}

\author{
Deniz ERGUDEN*, Mevlut GURLEK, and Cemal TURAN \\ Department of Marine Sciences, Faculty of Marine Sciences and Technology, Iskenderun Technical University, \\ Iskenderun, Hatay, Turkey
}

Erguden D., Gurlek M., Turan C. 2018. Confirmed occurrence of moontail bullseye, Priacanthus hamrur (Actinopterygii: Perciformes: Priacanthidae), in the Mediterranean Sea with first record off the coast of Turkey. Acta Ichthyol. Piscat. 48 (4): 387-391.

\begin{abstract}
A new Lessepsian migrant, moontail bullseye, Priacanthus hamrur (Forsskål, 1775), is recorded for the second time from the Mediterranean Sea, and for the first time from Turkey. A single male specimen of $P$. hamrur was caught at a depth of about $30 \mathrm{~m}$, off the Konac1k harbour (Arsuz coast, Gulf of Iskenderun, Turkey) on 18 December 2017, by a longline. The present paper reports the confirmed record of $P$. hamrur in the eastern Mediterranean with the first record off the coast of Turkey. This species is probably a Red Sea immigrant entering the Mediterranean Sea through the Suez Canal. With the present report, the number of priacanthid species reported in the Mediterranean Sea has reached four.
\end{abstract}

Keywords: Priacanthidae, confirmed record, Lessepsian migrant, Mediterranean Sea

\section{INTRODUCTION}

Since the opening of the Suez Canal in 1869, it has provided a significant pathway for the introduction of many alien species into the Mediterranean Sea (Zenetos et al. 2012, Katsanevakis et al. 2014). This "invasion corridor" undoubtedly facilitated the introduction (passage) of alien fish species from the Suez Canal into Turkey marine waters. Therefore, several alien fish species have been reported in the marine waters of Turkey (Erguden et al. 2017, Gürlek et al. 2017).

The family Priacanthidae is a relatively small taxon with 19 species accommodated within four genera (in Indo-Pacific region with 15 species and four species in the Atlantic) (Starnes 1988, Iwatsuki et al. 2012, Bineesh et al. 2016). This epibenthic predatory fish occurs primarily in rocky or coral habitats at depths from 8 to $250 \mathrm{~m}$ (Starnes 1988, Lieske and Myers 1994).

The family Priacanthidae is represented in the Red Sea by one genus and three species: Priacanthus blochii Bleeker, 1853, Priacanthus hamrur (Forsskål, 1775), and Priacanthus sagittarius Starnes, 1988 (see Goren and Dor 1994, Randall 1994, Starnes 1988). However, the genus Priacanthus Oken, 1817 is represented in the Mediterranean Sea by four species: the Atlantic bigeye, Priacanthus arenatus Cuvier, 1829, known from the western and northern Mediterranean Sea (Froese and Pauly 2018), the moontail bullseye, P. hamrur, the
Indo-Pacific arrow bulleye, $P$. sagittarius, and the arrow bullseye, Priacanthus prolixus Starnes, 1988, found in eastern Mediterranean (Goren et al. 2010, Golani et al. 2011, Farrag et al. 2016, Gürlek et al. 2017).

The moontail bullseye, Priacanthus hamrur, belongs to the family Priacanthidae that is represented by the genus Priacanthus which consists of 12 valid species globally (Froese and Pauly 2018). Priacanthus hamrur has a wide Indo-West Pacific distribution from the Red Sea and southern Africa to French Polynesia, north to southern Japan, to southern Australia. (Fricke 1999).

In 1980, a specimen identified as Priacanthus hamrur was collected off Mahdia, Tunisia (Abdelmoleh 1981). Upon this record, the presence of this species in the Mediterranean was mentioned in checklists provided by Bradai (2004) and Golani and Bogorodsky (2010). To date, $P$. hamrur has not been recorded from the eastern Mediterranean Sea, Turkey. Thus, the present paper confirms the occurrence of $P$. hamrur in the Mediterranean Sea with the first record off the coast of Turkey.

\section{MATERIAL AND METHODS}

A single specimen of Priacanthus hamrur was caught at a depth of $30 \mathrm{~m}$ off the Konacik harbour (Arsuz coast, Gulf of Iskenderun, eastern Mediterranean, Turkey) on 18 December 2017 by a longline (Fig. 1). The captured specimen was taken to the Laboratory of Molecular Ecology and Fisheries

" Correspondence: Dr. Deniz Ergüden, Deniz Bilimleri Bölüm, Deniz Bilimleri ve Teknolojisi Fakültesi, İskenderun Teknik Üniversitesi, 31220 İskenderun, Hatay, Turkey, phone: (+90) 3266141873, fax: (+90) 3266141877, e-mail: (DE)deniz.erguden@iste.edu.tr, (MG) mevlut.gurlek@iste.edu.tr, (CT) cemal.turan@iste.edu.tr. 
Genetics Laboratory, Iskenderun Technical University for further examination, where the main morphometric measurements were collected by means of a digital calliper, with the accuracy of $0.01 \mathrm{~mm}$. The specimen was identified according to Starnes (1988). The collected specimen was preserved in 4\% formalin and deposited in the Museum of the Faculty of Marine Sciences and Technology, Iskenderun Technical University, (Fig. 2) (MSM-PIS/2017-5).

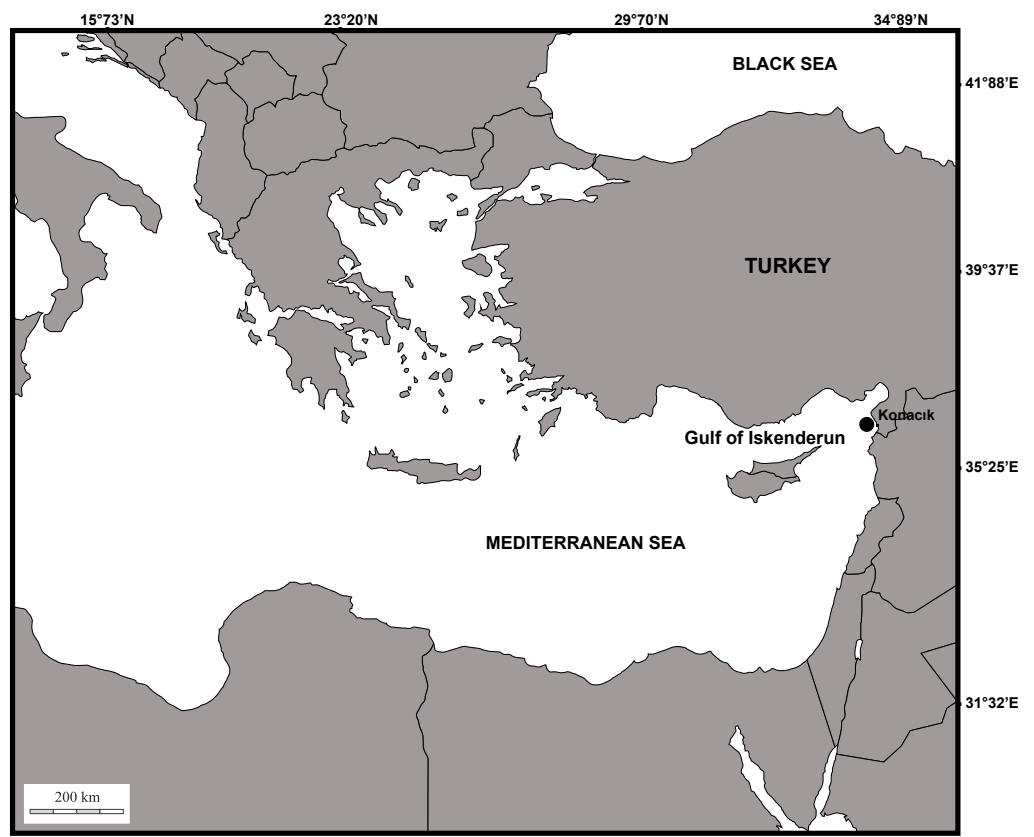

Fig. 1. Map showing record location (•) of moontail bullseye, Priacanthus hamrur the Gulf of Iskenderun, Turkey (Eastern Mediterranean)

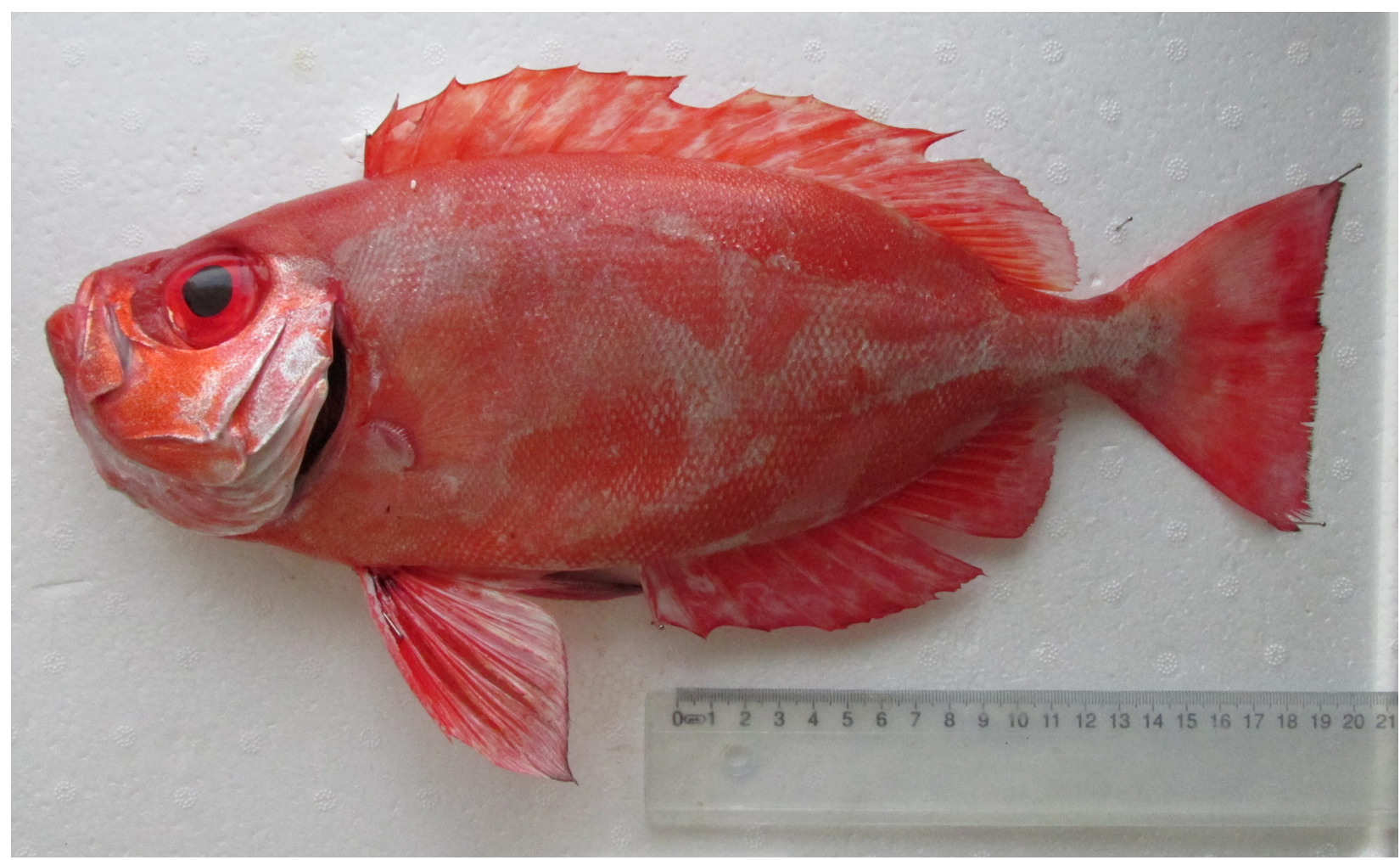

Fig. 2. Moontail bullseye, Priacanthus hamrur (Forsskål, 1775), captured in the Gulf of Iskenderun, Turkey (Eastern Mediterranean) 


\section{RESULTS}

The captured male specimen of moontail bullseye, Priacanthus hamrur, was $367-\mathrm{mm}$ long (total length, TL) and weighed $760.59 \mathrm{~g}$. The above-mentioned specimen had the following features: Dorsal fin rays $\mathrm{X}+13$ anal fin rays III +15 , pectoral fin rays 16 , and caudal fin rays 20, Total number of gill rakers on anterior gill arch 26, 21 on lower limb and 5 upper limb of first arch, 80 in scales lateral line series, below lateral line 28, above lateral line 24, lateral line scales 70 , vertical scale rows 48. Body depth at sixth dorsal-fin spine 2.6 times in standard length, SL. The body well compressed. Eyes are large. Mouth is oblique with a protruding lower jaw and mouth nearly vertical and snout long. Posterior and lower margins of preopercle finely serrated. Caudal fin emarginate. Distinguishing meristic and morphometric characteristics of the specimen are given in Table 1 and comparison other Mediterranean previous priacanthid records is presented in Table 2.

Table 1

Morphometric and meristic measurements of Priacanthus hamrur captured in the Gulf of Iskenderun, Turkey (Eastern Mediterranean)

\begin{tabular}{lc}
\hline \multicolumn{1}{c}{ Morphometric characters [mm] } & Value \\
\hline Total length (TL) & 367 \\
Standard length (SL) & 285 \\
Head length (HL) & 64.77 \\
Head depth & 60.03 \\
Maximum body depth & 109.30 \\
Eye diameter & 26.23 \\
Inter-orbital width & 19.48 \\
Distance between orbit and upper lip & 36.09 \\
Distance between upper lip and dorsal fin & 77.62 \\
Pre-orbital length & 14.73 \\
Post-orbital length & 43.56 \\
Pre-dorsal fin length & 69.56 \\
Post-dorsal fin length & 26.2 \\
Pre-pelvic fin length & 78.85 \\
Pre-pectoral fin length & 67.97 \\
Pre-anal fin length & 15.0 \\
Caudal peduncle length & 26.72 \\
Upper jaw length & 40.75 \\
Anal fin length & 117.21 \\
Pelvic fin length & 85.84 \\
Pectoral fin length & 43.13 \\
\hline Meristic characters & \\
\hline Total number of gill rakers on 1st gill arch & 26 \\
Scales in lateral line series & 80 \\
Vertical scale row & 48 \\
Number of dorsal fin ray spines & $\mathrm{X}+13$ \\
Number of anal spines & $\mathrm{I}+15$ \\
Number of pelvic spines & 16 \\
Number of pectoral rays & 20 \\
Number of caudal fin rays & \\
\hline
\end{tabular}

The maximum body depth was measured at sixth dorsal fin spine.
Colour (fresh specimen). Body is pink to red with broad red bands. There is a row of 15 small dark spots along the lateral line. Fins are red to light pink. Pelvic fins are red with a black spot at the fin base. Caudal fin has a concave margin which may be lunate.

\section{DISCUSSION}

In the present study, the moontail bullseye, Priacanthus hamrur, was identified according to Starnes (1988). All measurements and counts, the morphological description, and colour were consistent with the descriptions given by Starnes (1988) and Philip (1994). The moontail bullseye, $P$. hamrur, is closely related to the Priacanthus meeki Jenkins, 1903 and the Atlantic P. arenatus, with differences only in meristic counts and morphometry (Starnes 1988). Priacanthus hamrur by having capable of quickly altering to pinkish silver with six red bars on body and one extending ventrally from eyes and a black spot at base of first 3 pelvic rays (Randall et al. 1990). The low number of gill rakers (24-26) can distinguish it from its Atlantic congeneric Priacanthus arenatus (28-31). Besides, P. hamrur can be distinguished from $P$. meeki by the lateral series counts (79-96 for $P$. hamrur, 104-115 for $P$. meeki) and more compressed body (Starnes 1988, Motomura et al. 2001). In addition, the specimen of $P$. hamrur can be distinguished from other two priacanthid species $P$. blochii, and $P$. sagittarius differ from in the number of gill rakers (24-26 in P. hamrur; 1722, in P. blochii; 19-21, in P. sagittarius) (Starnes 1988, Ramachandran and Varghese 2009).

Moreover, Priacanthus hamrur is almost identical in appearance to the $P$. prolixus. The characteristic differences between the two species are the total number of gill rakers (24-26 for P. hamrur, 29-31 for P. prolixus), and much more elongated body structure (body depth at sixth dorsal fin spine about 2.6 to 2.8 times in standard length for $P$. hamrur, body depth at sixth dorsal fin spine 3 or more times in standard length for P. prolixus (see Philip 1994, Gürlek et al. 2017).

Bineesh et al. (2016) reported in a recent phylogenetic study using two (16s rRNA, and COI) mtDNA segments that the closest genetic similarity was observed between $P$. hamrur and P. prolixus from Indian samples. However, the above-mentioned authors suggested that a more detailed analysis with wide geographical sampling would reveal the true extent of speciation in this priacanthid species.

Priacanthus hamrur is a common inhabitant of reef slopes. Priacanthus hamrur is a nocturnal species living in tropical marine waters on outer slopes and in lagoons at depths of 8 to 250 meters. The moontail bullseye, can sometimes form schools in oceans (Kuiter and Tonozuka 2001). It feeds on small fishes, crustaceans, and other small invertebrates (Fischer et al. 1990). Male P. hamrur can reach a maximum length (TL) of $45 \mathrm{~cm}$, but they commonly reach $40 \mathrm{~cm}$ (Bouhlel 1988, Froese and Pauly 2018).

The presently reported study, $P$. hamrur is reported for the first time from the Mediterranean Sea. The occurrence of this species in the Mediterranean Sea is most probably due to migration from the Red Sea via the Suez Canal. 
A comparison of morphometric measurements

and meristic counts of Priacanthus hamrur captured

in the Gulf of Iskenderun, Turkey (Eastern Mediterranean) with closely related priacanthid species

\begin{tabular}{|c|c|c|c|c|c|}
\hline \multirow{2}{*}{ Measurements } & \multirow{2}{*}{$\begin{array}{l}\text { P. hamrur } \\
\quad n=1 \\
\text { This study }\end{array}$} & \multicolumn{2}{|c|}{$\begin{array}{l}\text { P. hamrur } n>1 \\
\text { Philip } 1994 \\
\end{array}$} & \multirow{2}{*}{$\begin{array}{c}\text { P. sagittarus } \\
n=1 \\
\text { Goren et al. } \\
2010 \\
\end{array}$} & \multirow{2}{*}{$\begin{array}{c}\text { P. prolixus } \\
n=1 \\
\text { Gürlek et al. } \\
2017 \\
\end{array}$} \\
\hline & & Mean & Range & & \\
\hline Head length [\%SL] & 22.7 & 31 & $27.9-33.7$ & 32.0 & 31.7 \\
\hline Eye diameter [\%HL] & 40.4 & 13.7 & $11.3-16$ & 48.0 & 29.6 \\
\hline Inter-orbital width [\%HL] & 30.0 & 7.7 & $6.3-8.9$ & 26.0 & 21.9 \\
\hline Body depth $[\% \mathrm{SL}]$ & 38.3 & 37 & $33.2-40.2$ & - & 27.2 \\
\hline Height of caudal peduncle $[\% \mathrm{SL}]$ & 9.4 & 8.6 & $6.8-9.9$ & - & - \\
\hline Distance between orbit and upper lip [\%HL] & 12.6 & - & & 9.0 & 20.7 \\
\hline Distance between upper lip to origin dorsal fin [\%SL] & 27.2 & - & & 28.0 & 25.3 \\
\hline Distance between upper lip to origin of anal fin [\%SL] & 50.5 & - & & 53.0 & 51.5 \\
\hline Length of the longest pectoral fin ray [\%SL] & 15.4 & 15.3 & $13.0-16.5$ & 15.0 & 16.4 \\
\hline Length of the longest pelvic fin ray $[\% \mathrm{SL}]$ & 31.3 & 28.8 & $26.0-32.2$ & 32.0 & 24.3 \\
\hline Length of the 1 st dorsal spine of dorsal fin [\%SL] & 5.1 & - & & 10.0 & 5.9 \\
\hline Length of the 2 nd dorsal spine of dorsal fin [\%SL] & 7.5 & - & & 11.0 & 8.1 \\
\hline Length of the 10 th dorsal spine of dorsal fin $[\% \mathrm{SL}]$ & 12.9 & - & & 21.0 & 13.0 \\
\hline Length of 1 st spine of anal fin $[\% \mathrm{SL}]$ & 6.0 & - & & 13.0 & 8.6 \\
\hline Length of 2 nd spine of anal fin [\%SL] & 9.1 & - & & 15.0 & 10.1 \\
\hline Length of 3rd spine of anal fin [\%SL] & 11.3 & - & & 20.0 & 11.1 \\
\hline \multicolumn{6}{|l|}{ Counts } \\
\hline Dorsal fin ray & $\mathrm{X}+13$ & $X+13-15$ & & $\mathrm{X}+13$ & $\mathrm{X}+14$ \\
\hline Pectoral fin ray & 16 & $18-19$ & & 19 & 20 \\
\hline Anal fin ray & III +15 & III $+14-15$ & & $\mathrm{III}+14$ & III +14 \\
\hline Lateral line scale & 70 & 79.6 & $70-90$ & - & 77 \\
\hline Scales in line series & 80 & 87.4 & $79-76$ & 75 & 87 \\
\hline Vertical scale row & 48 & 53.6 & $48-57$ & 46 & 46 \\
\hline Gill rakers & 26 & $24-26$ & & 18 & 29 \\
\hline
\end{tabular}

However, the captured single specimen of $P$. hamrur do not necessarily indicate an existence of an established population in the Mediterranean Sea and with the present report, the number of priacanthid species reported in the Mediterranean Sea has reached four.

\section{ACKNOWLEDGEMENTS}

The authors would like to thank Mr İsa Turan for providing the material for the presently reported study.

\section{REFERENCES}

Abdelmoleh A. 1981. Capture d'un priacanthe: Priacanthus hamrur (Forskal, 1775), poissons IndoPacifique, dan Ie eaux Tunisiennes. Bulletin de l'Institut National Scientifique et Technique d'Oceanographie et de Pêche Salammbô 8: 111-114.

Bineesh K.K., Gopalakrishnan A., Jena J.K., Basheer V.S., Mohitha C., Vineesh N., Joselet M., Pillai N.G.K. 2016. Molecular identification of bigeyes (Perciformes, Priacanthidae) from Indian waters. Mitochondrial DNA Part A 27 (6): 4638-4642. DOI: 10.3109/19401736.2015.1101593

Bouhlel M. 1988. Poissons de Djibouti. RDA International, Placerville CA, USA.
Bradai M.N., Quignard J.-P., Bouain A., Jarboui O., Ouannes-Ghorbel A., Ben Abdallah L., Zaouali J., Ben Salem S. 2004. Ichtyofaune autochtone et exotique des côtes tunisiennes: recensement et biogéographie. Cybium 28 (4): 315-328.

Erguden D., Kabaklı F., Uyan A., Doğdu S.A., Karan S., Gurlek M., Turan C. 2017. New record of diamondback puffer Lagocephalus guentheri Miranda Ribeiro, 1915 from the north-eastern Mediterranean, Turkey. Natural and Engineering Sciences 2 (3; Supplementary articles on pufferfish): 67-73.

Farrag M.M.S., Jawad L.A., Eldinl A., Elhaweet A.E.A.K. 2016. Occurrence of the arrow bulleye Priacanthus sagittarius (Teleostei: Priacanthidae) in the Egyptian coast of the Mediterranean Sea. Marine Biodiversity Records 9: e6. DOI: 10.1186/s41200016-0010-0

Fischer W.I., Sousa C., Silva A., de Freitas J.M., Poutiers W., Schneider T.C., Borges J.P., Massinga F.A. 1990. Fichas FAO de identificaçao de espécies para actividades de pesca. Guia de campo das espécies comerciais marinhas e de águas salobras de Moçambique. [FAO species identification sheets for fishing activities. Field Guide to marine commercial 
and brackish water species from Mozambique.] Publicaçao preparada em collaboraçao com o Instituto de Investigaçao Pesquiera de Moçambique, com financiamento do Projecto PNUD/FAO MOZ/86/030 e de NORAD. [Publication prepared in collaboration with the Fisheries Research Institute of Mozambique, with funding from the UNDP/FAO Project MOZ/86/030 and NORAD.] FAO, Rome. [In Portuguese.]

Fricke R. 1999. Fishes of the Mascarene Islands (Réunion, Mauritius, Rodriguez): An annotated checklist, with descriptions of new species. Theses Zoologicae. Vol. 31. Koeltz Scientific Books, Königstein, Germany.

Froese R., Pauly D. (eds.) 2018. FishBase. [Version 06/2018] http://www.fishbase.org

Golani D., Bogorodsky S.V. 2010. The fishes of the Red Sea-Reappraisal and updated checklist. Zootaxa 2463: 1-135.

Golani D., Sonin O., Edelist D. 2011. Second records of the Lessepsian fish migrants Priacanthus sagittarius and Platax teira and distribution extension of Tylerius spinosissimus in the Mediterranean. Aquatic Invasions 6 (Suppl. 1): S7-S11. DOI: 10.3391/ai.2011.6.S1.002

Goren M., Dor M. 1994. An updated checklist of the fishes of the Red Sea-CLOFRES II. Israel Academy for Sciences and Humanities. Jerusalem.

Goren M., Stern N., Galil B.S., Diamant A. 2010. First record of the Indo-Pacific arrow bulleye Priacanthus sagittarius Starnes, 1988 in the Mediterranean Sea. Aquatic Invasions 5 (Suppl. 1): S45-S47. DOI: 10.3391/ai.2010.5.S1.011

Gürlek M., Ergüden D., Turan C. 2017. First record elongate bulleye Priacanthus prolixus Starnes, 1988 in the Mediterranean Sea. Natural and Engineering Sciences 2 (1): 44-47.

Iwatsuki Y., Matsuda T., Starnes W.C., Nakabo T., Yoshino T. 2012. A valid priacanthid species, Pristigenys refulgens (Valenciennes 1862), and a redescription of $P$. niphonia (Cuvier in Cuvier et Valenciennes, 1829) in the Indo-West Pacific (Perciformes: Priacanthidae). Zootaxa 3206: 41-57.

Katsanevakis S., Wallentinus I., Zenetos A., Leppäkoski E., Çinar M.E., Oztürk, B., Grabowski M., Golani D., Cardoso A.C. 2014. Impacts of invasive alien marine species on ecosystem services and biodiversity: A pan-European review. Aquatic Invasions 9 (4): 391423. DOI: 10.3391/ai.2014.9.4.01

Kuiter R.H., Tonozuka T. 2001. Pictorial guide to Indonesian reef fishes. Part 1. Eels-snappers,
Muraenidae-Lutjanidae. Zoonetics, Seaford VIC, Australia.

Lieske E., Myers R. 1994. Coral reef fishes. Indo-Pacific and Caribbean including the Red Sea. Collins Pocket Guide. Haper Collins Publishers, London, UK.

Motomura H., Burhanuddin A.I., Kimura S., Iwatsuki. Y. 2001. [Fresh color notes for Priacanthus prolixus Starnes, 1988 from the West Coast of India (Perciformes: Priacanthidae)]. Biogeography 3: 7781. [In Japanese with English abstract.]

Philip K.P. 1994. Studies on the biology and fishery of the fishes of the family Priacanthidae (Pisces: Perciformes) of Indian waters. Doctor of Philosophy Thesis, Cochin University of Science and Technology, Cochin, India.

Ramachandran S., Varghese B.C. 2009. New record of arrowfin bigeye Priacanthus sagittarius Starnes, 1988 (Pisces: Priacanthidae) from Indian waters with taxonomic account. Journal of the Marine Biological Association of India 51 (2): 217-222.

Randall J. 1994. Twenty-two new records of fishes from the Red Sea. Fauna of Saudi Arabia 14: 259-275.

Randall J.E., Allen G.R, Steene R.C. 1990. Fishes of the Great Barrier Reef and Coral Sea. University of Hawaii Press, Honolulu HI, USA.

Starnes W.C. 1988. Revision, phylogeny and biogeographic comments on the circumtropical marine percoid fish family Priacanthidae. Bulletin of Marine Science 43 (2): 117-203.

Zenetos A., Gofas S., Morri C., Rosso A., Violanti D., García Raso J.E., Çinar M.E., Almogi Labin A., Ates A.S., Azzuro E., Ballesteros E., Bianchi C.N., Bilecenoglu M., Gambi M.C., Giangrande A., Gravili C., Hyams-Kaphzan O., Karachle V., Katsanevakis S., Lipej L., Mastrototaro F., Mineur F., Pancucci Papadopoulou M.A., Ramos Esplá A., Salas C., San Martín G., Sfriso A., Streftaris N., Verlaque M. 2012. Alien species in the Mediterranean Sea by 2012. A contribution to the application of European Union's Marine Strategy Framework Directive (MSFD). Part 2. Introduction trends and pathways. Mediterranean Marine Science 13 (2): 328352. DOI: $10.12681 / \mathrm{mms} .327$

Received: 27 February 2018 Accepted: 8 October 2018 Published electronically: 31 December 2018 